\title{
Moving from MPAs to Area-based Management Measures in the South China Sea
}

\author{
Youna Lyons, ${ }^{\text {a }}$ Robert Beckman, ${ }^{\text {a }}$ Loke Ming Chou ${ }^{\mathrm{b}}$ and Danwei Huang ${ }^{\mathrm{c}}$ \\ a Centre for International Law, National University of Singapore, Bukit \\ Timah Campus, Singapore 259770 \\ b Tropical Marine Science Institute, National University of Singapore, \\ Singapore 119227 \\ c Department of Biological Sciences, National University of Singapore, \\ Singapore 117543
}

\begin{abstract}
Evolution of the marine protected area discourse into an area-based management tool may provide an avenue for a more progressive approach to protection of the Spratly seamounts. A first step could be the recognition of the Spratlys as an ecologically or biologically significant area (E BSA) under the Convention on Biological Diversity. This purely scientific recognition exercise would be without prejudice to the sovereignty, sovereign rights and jurisdiction of coastal States or State claiming sovereignty over the islands. Furthermore, it is up to the States concerned to later agree on specific restriction on activities in these areas as deemed necessary. This article shows that there are sufficient published data to justify that the Spratly seamounts meet the scientific criteria of an E BSA. However, it also proposes areas that may be prioritised on the basis of distinctive species composition of reef-building corals in the South China Sea.
\end{abstract}

\section{Keywords}

United Nations Convention on the Law of the Sea (LOSC) - marine protected area (M PA) - area-based management tool (АВМ T) - Ecologically or Biologically Significant Area (EBSA) - South China Sea 


\section{Introduction}

Calls from academics for the establishment of different types of marine protected areas (MPAs) and networks of MPAs in the disputed Spratlys area ${ }^{1}$ have so far been unsuccessful. ${ }^{2}$ Calls by President Ma of Taiwan and Justice Carpio of the Philippines to engage on a path towards the establishment of a peace park and involvement of conservation organisations do not appear to have resulted in States adopting any protective measures to be respected by their nationals and vessels flying their flag. ${ }^{3}$

However, the duty to protect and preserve the marine environment is well established under international law and includes rare or fragile ecosystems and the habitats of depleted, threatened or endangered species and other forms of marine life. ${ }^{4}$ The obligation of cooperation in the fulfilment of this

1 For a presentation and balanced analysis of the South China Sea (scs) dispute, see R Beckman, 'The UN Convention on the Law of the Sea and the maritime disputes in the South China Sea' (2013) 107 American Journal of International Law 142-163; L Reed and K Wong, 'Marine entitlements in the South China Sea: The arbitration between the Philippines and China' (2016) 110 American Journal of International Law 746-760; E Franckx and M Benatar, 'Introduction: The South China Sea: An international law perspective' (2017) 32 International Journal of Marine and Coastal Law 193-237; and more generally S Jayakumar, T Koh, R Beckman, T Davenport and H Duy Phan (eds), The South China Sea Arbitration: The Legal Dimension (Edward Elgar, Cheltenham, 2018).

2 See, for example, JW McManus, 'The Spratly Islands: A marine park?' (1994) 23 Ambio 181186; JW McManus, KT Shao and SY Lin, 'Toward establishing a Spratly Islands International Marine Peace Park: Ecological importance and supportive collaborative activities with an emphasis on the role of Taiwan' (2010) 41 Ocean Development \& International Law 270-280; HD Vu, Marine Protected Areas Network in the South China Sea: Charting a Course for Future Cooperation (Martinus Nijhoff, Leiden and Boston, 2014); CH Nguyen and HD Vu, 'Building a regional network and management regime of marine protected areas in the South China Sea for sustainable development' (2015) 18 Journal of International Wildlife Law and Policy 128-138; D Huang et al., 'Conservation of reef corals in the South China Sea based on species and evolutionary diversity'(2016) 25 Biodiversity Conservation 331-344.

3 YH Song, 'The South China Sea Workshop process and Taiwan's participation' (2010) 41 Ocean Development and International Law 253-269, at p. 262; S. Mollman, 'A decades-old idea for the scs resurfaces: Make a contested area a marine park, instead', Quartz, 20 July 2016, available at https://qz.com/735741/a-decades-old-idea-for-the-south-china-sea-resurfaces-make -a-contested-area-a-marine-park-instead/; accessed 1 May 2019.

4 United Nations Convention on the Law of the Sea (Montego Bay, 10 December 1982, in force 16 November 1994) 1833 UNTS 396 (LOSC), Articles 192, 194(5). Several international court decisions have insisted that States have an obligation to act with due diligence in order to protect the marine environment. See Case Concerning Pulp Mills on the River Uruguay (Argentina v. Uruguay), Judgment of 20 April 2010, ICJ Reports 2010 14, paras 101, 197; International Tribunal on the Law of the Sea (ITLOS) Case No. 17 - Responsibilities and Obligations of 
obligation, directly or through international organisations, is also well established and entails a procedural due diligence obligation to consult meaningfully and in good faith. ${ }^{5}$

This article first investigates the evolution of the international MPA discourse and the development of area-based management measures for the protection and conservation of the marine environment. Area-based management measures designate a wider category of measures than MPAs and may offer a stepping stone towards effective protection of the marine environment in disputed areas of the South China Sea. In the second part, this article discusses international instruments that promote the utilisation of different types of area-based management tools (АВМтs). It focuses in particular on the prospects for the application of the 1992 Convention on Biological Diversity $(\mathrm{CBD})^{6}$ and the identification of Ecologically or Biologically Significant Areas $(\text { EBSAs })^{7}$ in disputed areas in the South China Sea. The third part discusses the measures that could be envisaged at a later stage from a legal perspective under the United Nations Convention on the Law of the Sea (LOSC) $)^{8}$ and from a political perspective.

States Sponsoring Persons and Entities with Respect to Activities in the Area, Advisory Opinion, 1 February 2011, ITLOS Reports 2011, 10, paras 110-116; ITLOS Case No. 21 - Request for an Advisory Opinion Submitted by the Sub-Regional Fisheries Commission (SRFC), Advisory Opinion, 2 April 2015, paras 116-124; In the Matter of the South China Sea Arbitration before and Arbitral Tribunal Constituted under Annex VII to the 1982 United Nations Convention on the Law of the Sea between the Republic of the Philippines and the People's Republic of China, Award, 12 July 2016, Permanent Court of Arbitration (PCA), PCA Case No. 2013-19 (sCS Arbitration Award).

5 In two international court cases the Tribunal held that the States' obligation to cooperate is a fundamental principle in the prevention of pollution of the marine environment under Part XII of the LOSC and general international law. See itLos Case No. 10 - The MOX Plant Case (Ireland v. United Kingdom), Order of 3 December 2001, para 82; ITLOS Case No. 12 Case Concerning Land Reclamation by Singapore in and around the Straits of Johor (Malaysia v. Singapore), Order of 8 October 2003, para 92.

6 Convention on Biological Diversity (Rio de Janeiro, 5 June 1992, in force 29 December 1993) 1760 UNTS 79 (CBD).

7 Criteria for the identification of ecologically or biologically significant areas (EBSAs) were adopted by СвD COP9 Decision IX/20 (2008) Marine and Coastal Biodiversity, para 14 and Annex I. This process followed the impetus provided in 2004 by the United Nations General Assembly (UNGA) resolution that called for area-based approaches and tools for the conservation and sustainable use of marine biodiversity in areas beyond national jurisdiction. UNGA, Oceans and the Law of the Sea, UN Doc. A/RES/59/24 (4 February 2005), paras 70-73.

$8 \operatorname{LOSC}(\mathrm{n} 4)$. 


\section{From MPAs to Area-based Management Measures under International Ocean Law and Policy}

\section{Definition of an MPA under International Law}

Under international law, a protected area is defined in Article 2 of the CBD as 'a geographically defined area, which is designated or regulated and managed to achieve specific conservation objectives'. This definition applies to protected areas in both terrestrial and marine areas. This is the only definition of protected area contained in a global convention applicable to the marine environment. An important characteristic of this definition is that the objective of the designation is conservation and that steps are expected to be taken to ensure that this objective is fulfilled. In 2004, this general definition was interpreted by the Conference of the Parties (COP) to the $\mathrm{CBD}$ in the context of the marine environment as

[an] area within or adjacent to the marine environment, together with its overlying waters and associated flora, fauna and historical and cultural features, which has been reserved by legislation or other effective means, including custom, with the effect that its marine and/or coastal biodiversity enjoys a higher level of protection than its surroundings. ${ }^{9}$

The language used in both definitions suggests that an MPA does not require legislation. The definition of the СвD mentions that a protected area may be 'designated or regulated and managed' [emphasis added]. The 2004 interpretation by the COP adds that it may be designated by 'legislation or other effective means'. This echoed the recognition made at the 5 th World Parks Congress in Durban of the value of other conservation governance models such as the establishment and management of protected areas by indigenous communities according to traditional mechanisms. ${ }^{10}$ Although this interpretation did not include conservation as a key component, it may be seen as implied since it is included in the definition of the СвD which is being interpreted.

In the 2015 Chagos Arbitration case, the arbitral tribunal considered that, in the context of LOSC and Article 194(5), an M PA is a measure focused 'primarily

9 The CBD COP 'welcomed' the reports of the Ad Hoc Technical Expert Group on Marine and Coastal Areas which defines marine and coastal areas, thereby endorsing it. Report of the Ad Hoc Technical Expert Group on Marine and Coastal Protected Areas, UNEP/CBD/ SBSTTA $/ 8 /$ INF/7.

10 JP Brosius, 'Indigenous peoples and protected areas at the World Parks Congress' (2004) 18 Conservation Biology 6o9-612; F Berkes, 'Community conserved areas: Policy issues in historic and contemporary context' (2009) 2 Conservation Letters 20-25. 
on conservation and the preservation of marine ecosystems'. Importantly, the tribunal decided to not include biodiversity in the definition despite it being mentioned several times by the parties as being an objective of this measure. ${ }^{11}$ However, the primary purpose of conservation and preservation is highlighted by the tribunal.

By contrast, the United Nations Food and Agriculture Organization (FAO) defines an MPA, for the purpose of the Responsible Fisheries Guidelines, as 'any marine geographical area that is afforded greater protection than the surrounding waters for biodiversity conservation or fisheries management purposes $^{\prime 2}$ [emphasis added]. A fisheries management area, such as a seasonal area closure, would therefore qualify as an MPA, although it may not expressly stipulate that it is established for conservation purpose and may or may not contribute durably to the conservation of the area. Interestingly, other international instruments that seek to set aside marine and coastal areas to preserve particular environmental features and were negotiated in the early 1970s to identify wetlands of international importance and World Heritage Sites ${ }^{13}$ do not use the term 'protected area' or MPA.

\section{Co-evolution of MPA Discourses}

A lack of a common understanding on expected protective measures and activities which may or may not be permitted in MPAs appears to have allowed an evolution of the concept of the MPA since the 1970s or even earlier. The definitions adopted by the сво in 1992 and later were also general enough to allow these processes to continue.

Several authors conceptualised that as the movement for the establishment of protected areas grew and strengthened, it started to encompass new framing and purposes for protected areas. ${ }^{14}$ The initial perception of conservation

11 In the matter of the Chagos Marine Protected Area Arbitration (Republic of Mauritius v. United Kingdom of Great Britain and Northern Ireland), Award, 18 March 2015, PCA Case No. 2011-03, para 538 .

12 United Nations Food and Agriculture Organization (FAO), 'Fisheries Management 4, Marine Protected Areas and Fisheries', FAO Technical Guidelines for Responsible Fisheries (FAO, Rome, 2011); available at http://www.fao.org/docrep/o15/i2ogoe/i2ogoe.pdf; accessed 1 May 2019.

13 The 1971 Convention on Wetlands of International Importance especially as Waterfowl Habitat (Ramsar, 2 February 1971, in force 21 December 1975) 996 UNTS 245 (Ramsar Convention) and the 1972 Convention Concerning the Protection of the World Cultural and Natural Heritage (Paris, 23 November 1972, in force 15 December 1975) 1037 UNTS 151 (UNESco World Heritage Convention), respectively.

14 GM Mace, 'Whose conservation? Changes in the perception and goals of nature conservation require a solid scientific basis' (2014) 345(6204) Science 1558-1560; C Corson 
was focused on protection of 'nature for itself' in its pristine form and favoured setting aside large areas that had been the subject of minimal human impact to conserve them. This approach to protected areas could even lead to the displacement of the local population living within a designated protected area. ${ }^{15}$ New competing conservation notions and narratives would appear to have since entered the protected area movement to create a shared discourse coalition for the establishment of protected areas.

New interests and narratives include a focus on local population and social benefits from protected areas through a community-based conservation approach. The appearance of these new narratives has been accompanied by the introduction of private actors in the discussion, including environmental non-governmental organisations and interest groups from the civil society such as indigenous and local communities. In turn these new actors favoured the development of market-based mechanisms in the political conservation discourse such as the concept of ecosystem service as a basis for establishing protected areas, including through the assessment of the carbon storage capacity of a protected area to mitigate climate change. Other ecosystem services are, for instance, protection against erosion and wave surges provided by coral reefs and mangroves and the nutrient cycling function of mangroves. ${ }^{16}$ These different approaches to conservation assess the effectivity of protected areas in a different manner, and range from area coverage and biodiversity accounting to social benefits, ecosystem services and even sustainable uses.

Published literature on MPAs and on State practice reflects these different narratives of competing views behind the establishment of protected areas. It first shows that MPAs became a global concept as a conservation tool of choice in the 1970s when they were first called for by scientists and global conservation initiatives such as the Regional Seas Programme of the United Nations Environment Programme and the National Parks Commission of the International Union for Conservation of Nature (IUCN), which later became the World Commission on Protected Areas (WCPA). ${ }^{17}$ Many MPAs were established by States in the 1970s and 1980s, with an estimated 1,000 MPAs in

et al., 'Everyone's solution? Defining and redefining protected areas at the Convention on Biological Diversity' (2014) 12 Conservation and Society 190-2O2.

15 Ibid.

16 Corson et al. (n 14).

17 S Wells et al., 'Building the future of MPAs - lessons from history' (2016) 26 Aquatic Conservation: Marine and Freshwater Ecosystems 101-125; KL Cochrane, 'Marine protected areas as management measures: Tools or toys?' in M Nordquist, R Long, T Heidar and J Norton Moore (eds), Law, Science and Ocean Management (Center for Oceans Law and Policy, Virginia University, Charlottesville, VA, 2007) 701-737. 
87 countries by $1986 .{ }^{18}$ In the 199 os the concept was subsequently developed in the СвD and the importance of protected areas was highlighted in several soft law instruments. ${ }^{19}$ As the movement grew, strengthened and succeeded in pushing international bodies to recommend protected area targets, other competing narratives not based on pure conservation started developing and feeding the MPA movement. However, the competing and often contradictory interests represented by the overall 'MPA coalition' result in a lack of a common understanding of (1) what a protected area might be, (2) what human activities may be permitted and (3) what the main purpose of such activities might be.

\section{MPAs and Area Coverage Targets in International Ocean Policy and the Development of Other Area-based Conservation Measures and Management Tools}

It seems that the first tentative qualitative target to establish MPAs with a timeframe, and agreed by an intergovernmental body, was in the Plan of Implementation of the 2002 World Summit for Sustainable Development (2002 WSSD) in Johannesburg. It was agreed that in order to fulfil the plan, it was necessary for States to establish MPAs, including 'representative networks' of MPAs, 'by 2012 and time/area closures for the protection of nursery grounds and periods. ${ }^{20}$ The exact same target was reiterated in the United General Assembly Resolution (UNGA) 57/141 on Oceans and Law of the Sea dated

18 ME Silva, EM Gately and I Desilvestre, A Bibliographic Listing of Coastal and Marine Protected Areas: A Global Survey, WHOI-86-11 (Woods Hole Oceanographic Institution, Woods Hole, MA, 1986) doi:10.1575/1912/7543. These included mPAs that were World Heritage Sites (such as the Great Barrier Reef, which was designated in 1981) under the 1972 UnESCo World Heritage Convention (n 13) and Ramsar Wetlands Sites under the 1971 Ramsar Convention (n 13); see also Wells et al. (n 17).

19 In Agenda 21, adopted in 1992 at the United Nations Conference on Environment and Development, Rio de Janeiro, Brazil, Chapter 17 mentions in three paragraphs that States should designate protected areas in order to protect, inter alia, critical habitats, i.e., for conservation of the marine environment (paras $17(7), 17(8)(\mathrm{d})$ and $17(85)$ ); available at https://sustainabledevelopment.un.org/content/documents/Agenda21.pdf; accessed 1 May 2019. The СвD itself calls for protected areas to protect biodiversity in Article 8 on in-situ conservation with no distinction of the terrestrial and marine environment. In 1995, СBD COP2 Decision II/10 on conservation and sustainable use of marine and coastal biological diversity (the Jakarta Mandate) recommend States to 'establish or consolidate representative systems of marine and coastal protected areas' (СВD Decision II/10 para (b) supporting the Subsidiary Body on Scientific Technical and Technological Advice (SBSTTA) Recommendation 1/8 para 11).

20 WSsD Plan of Implementation, UN Doc. A/Conf.199/L.1 (26 June 2002), para 31(c), available at https://sustainabledevelopment.un.org/milesstones/wssd; accessed 1 May 2019. 
21 February 2003, and annually since. ${ }^{21}$ However, the focus on 'time/area closures for the protection of nursery grounds and periods' was replaced in 2004 by a more general emphasis on vulnerable and threatened ecosystems. ${ }^{22}$ Until the 2002 WSSD, UNGA Resolutions on Oceans and Law of the Sea referred more generally to the protection and preservation of the marine environment, the title of Part XII of the LOSC.

СвD СОР7 (2004) set a similar qualitative target with a timeline but it introduced a new $10 \%$ quantitative target in Annex II to Decision VII/30 on 'Strategic plan: future evaluation of progress'. The language used is different than that used previously and can be construed as providing a slightly different guidance. As a measurement of Goal 1 to promote the conservation of the biological diversity of ecosystems, habitats and biomes, a target 1.1 of 'at least $10 \%$ of each of the world's ecological regions effectively managed' is provided in a provisional framework for goals and targets [emphasis added].$^{23}$ In 2010, СBD COP1O adopted the Aichi Targets in Decision X/2 which urge parties and other governments to implement the Strategic Plan for Biodiversity 2011-202O. Target 11 calls for 'at least $10 \%$ of coastal and marine areas, especially areas of particular importance for biodiversity and ecosystem services, are conserved through effectively and equitably managed, ecologically representative and well connected systems of protected areas and other effective area-based conservation measures [АВСм] and integrated into the wider ... seascapes' [emphasis added].$^{24}$ CBD COP14 (2018) adopted the following definition for 'other effective area-based conservation measures' in Decision XIV/8: 'a geographically

21 UNGA, Oceans and the Law of the Sea, UN Doc. A/RES/57/141 (21 February 2003), para 53, calls upon States to establish MPAs 'consistent with international law and based on scientific information, including representative networks by 2012 and time/area closures for the protection of nursery grounds and periods'. Until the United Nations Summit on Sustainable Development of 2012 (WSSD), all the resolutions emphasised the establishment of representative networks of MPAs by 2012. Following, the 2012 WSSD, the timeline included in UNGA resolutions was changed to 2020 on the basis of the target included in СвP COP1O Decision X/2 (2010).

22 UNGA, Oceans and the Law of the Sea, UN Doc. A/RES/58/240 (5 March 2004), para 54. This language has been further developed to acknowledge and follow the language adopted by the СвD and the FAO for the identification of ЕBSAs and vulnerable marine ecosystems (VMEs), respectively.

23 To note, these quantitative targets were designed to help assess progress towards targets in decision vi/26 on the Strategic Plan for the Convention on Biological Diversity, following Recommendation $9 / 10$ of the SBSTTA in UNEP/CBD/sBSTTA $/ 9 / 10$. This target of $10 \%$ 'should not be used to evaluate the level of implementation of the Convention in individual Parties or regions'. COP7 Decision vir/3o Strategic Plan: future evaluation of progress, UNEP/CBD/COP/DEC/VII/3O at paras 3 and 11 and Annex II. 
defined area other than a Protected Area, which is governed and managed in ways that achieve positive and sustained long-term outcomes for the in-situ conservation of biodiversity, with associated ecosystem functions and services and where applicable, cultural, spiritual, socio-economic and other locally relevant values..25

The language used by CBD COP7 in 2004 could suggest a pure conservation target with representativeness being measured through the coverage requirement applying to each ecological region of the world rather than globally. However, the Aichi Target introduces the notion that these areas may be of particular importance to ecosystem services rather than only biodiversity. It also introduced the possibility for effective АBCM as a valid alternative to 'equitably managed, ecologically representative and well-connected systems of protected areas'. This is confirmed by the definition adopted by the СвD СОР14 in November 2018.

The same evolution can be observed in the language of the resolutions of the UNGA. In 2017, the UNGA Resolution 'Our Future Our Action' called for 'effective and appropriate area-based management tools including MPAs and other integrated, cross-sectoral approaches, including marine spatial planning and integrated coastal zone management.' ${ }^{26}$ It also reiterated its commitment to achieve the targets of the Sustainable Development Goal (SDG) 14 to conserve and sustainably use the oceans, seas and marine resources for sustainable development. Target 14.5 is to 'conserve at least $10 \%$ of coastal and marine areas by 2020 , consistent with national and international law and based on the best available scientific information'. Achievement of this target is to be measured in coverage of protected areas in relation to marine areas. ${ }^{27} \mathrm{UNGA}$ $73 / 124$ on Oceans and law of the sea calls on States to implement the SDGs, but it does not include any reference to the targets or the indicators. It notes also the Aichi Target language with respect to protection of $10 \%$ of coastal and marine areas without endorsing it directly. Each of these recommendations uses

$25 \mathrm{CBD} / \mathrm{COP} / \mathrm{DEC} / 14 / 8$.

26 UNGA, Our Oceans, Our Future: Call for Action, 14July 2017, UN Doc. A/Res/71/312 (14 July 2017). Calls for area-based measures, including MPAS and the need that they be effectively managed, ecologically representative and well-connected, have been reiterated annually in the UNGA Resolution on Oceans and Law of the Sea. See, for example, UNGA A/72/L.18 dated 22 November 2017 and A/RES/67/78 dated 18 April 2013.

27 Targets and indicators of SDG 14, available at https://sustainabledevelopment.un.org/ sdg14; accessed 1 May 2019. The SDGs were created under UNGA Resolution A/RES/66/288 'The Future We Want' (11 September 2012), following the Conference on Sustainable Development in Rio de Janeiro in $2012($ Rio +20$)$ and the subsequent adoption of the 17 SDGs in UNGA Resolution, Transforming Our World: The 2030 Agenda for Sustainable Development, UN Doc. A/RES/70/1 (21 October 2015). 
slightly different language. Whilst the 2017 UNGA frames MPAs as one ABMT among others, Target 14.5 only invites to 'conserve' according to 'national and international law' rather than 'establish MPAs'. It is only the indicator adopted by the working group that refers to protected areas to measure implementation of the target.

There is neither a definition of АВмт in international law nor a generally accepted non-legal definition. In the context of the negotiations for an international legally binding instrument (ILBI) under the LOSC on the conservation and sustainable use of marine biological diversity of areas beyond national jurisdiction, the IUCN proposed that ABMTs be defined as 'regulations of human activity in a specified area to achieve conservation or sustainable resource management objectives.' ${ }^{28}$ The authors are of the view that ABMTs would be better described as 'measures adopted by the competent authority in a specified area that contribute to achieving conservation or sustainable resource management objectives' [emphasis added]. The IUCN reference to 'regulation' is inconsistent with the definition of the $\mathrm{CBD}$ that does not require regulation for an area to qualify as an MPA, a sub-category of ABMTs. Furthermore, such measures, if they do not include management of human activities within the area, may not be sufficient to achieve protection and conservation.

ABCMS and MPAs are therefore types of ABMTs. An interesting characteristic of АВMTs is that all the mechanisms developed internationally and regionally to identify sensitive marine areas on different ecological or oceanographic bases may meet this definition of an Авмт. By contrast, it is not clear whether they meet the definition of an MPA as this would depend on the perspective of the person or group applying the definition.

\section{Identification of Potential AвMTs in the South China Sea According to International Law}

\section{Relevant International Legal Instruments}

Many international instruments provide for the identification of maritime areas that present certain ecological characteristics and for the adoption of adequate measures in order to protect them and/or ensure sustainable uses of marine resources located within these areas. As a result, such marine areas and the resources or features that have been identified within them as being

28 IUCN, Measures such as Area-based Management Tools, including Marine Protected Areas (2016), available at http://www.un.org/depts/los/biodiversity/prepcom_files/area_based_ management_tools.pdf; accessed 1 May 2019. 
'sensitive' are expected to be subject to more protective measures than the surrounding waters. The term 'sensitive' is used in this context loosely ${ }^{29}$ to include a diversity of characteristics or values of a marine area that justify particular care and a more protective status.

International legal instruments that seek to identify such areas are very diverse and can be divided into two main categories. The first category concerns instruments, the main purpose of which is the conservation of different components of the marine environment. These instruments promote conservation of different components of the marine environment and conservation values. However, they provide limited specific guidance on activities that may occur or should be restricted within the sensitive areas that they seek to identify. This category includes the 1971 Ramsar Convention on the Protection of Wetlands of International Importance, ${ }^{30}$ the 1972 Unesco Convention concerning the Protection of the World Natural and Cultural Heritage, ${ }^{31}$ the 1979 Bonn Convention on the Conservation of Migratory Species of Wild Animals, ${ }^{32}$ the LOSC, ${ }^{33}$ and the CBD. ${ }^{34}$

The second category concerns sectoral regulations adopted by competent international organisations for specific uses of the sea in order to limit impacts from these activities in areas that are vulnerable to them. Globally, such regulations have been adopted by numerous international organisations. They include regulations adopted by the International Maritime Organization (IMO) to limit impacts from shipping on marine sensitive areas, regulations adopted by the FAO for the sustainable management of fisheries, and regulations adopted by the International Seabed Authority for seabed mining in areas beyond national jurisdiction. ${ }^{35}$

29 And not according to its ecological definition.

30 Ramsar Convention (n 13) for the identification, protection and wise use of 'wetlands of international importance' especially as waterfowl habitat.

31 UNESCO World Heritage Convention (n 13).

32 Convention on the Conservation of Migratory Species of Wild Animals (Bonn, 23 June 1979, in force 1 November 1983) 1651 UNTS 333 .

33 The provisions being specifically referred to in this context are Articles 192 and 194(5) which, together, provide for the States' obligation to act with due diligence to protect and preserve the marine environment, including the rare or fragile ecosystems as well as the habitat of depleted, threatened or endangered species and other forms of marine life.

34 On the history of the development of EBSAs, see n 6; see also DC Dunn et al., 'The Convention on Biological Diversity's Ecologically or Biologically Significant Areas: Origins, development and current status' (2014) 49 Marine Policy 137-145.

35 This list is not exhaustive, but it includes the most typical examples of sectoral regulations adopted at the global level to limit impacts from specific activities to sensitive marine areas. Other relevant examples would be, for example, the avoidance of sensitive areas in the selection of dump sites in the context of the application of the 1972 
However, this article proposes to focus in particular on measures adopted under the СвD to consider whether they could provide a mechanism conducive for the identification of an environmentally sensitive area in politically sensitive areas such as the Spratlys area in the South China Sea. Particular characteristics of the Spratlys area are that it is subject to sovereignty and maritime boundary disputes, it is isolated from the mainland of the littoral States, and it covers a large area in the South China Sea. The reasons for considering a mechanism under the CBD are twofold. First, the CBD has been adopted by all the claimant States in the Spratlys area. ${ }^{36}$ Second, the careful choice of language adopted by the COP to the CBD to define the concept and role of EBSAS results in this concept being particularly suited for collaboration in sensitive areas without prejudice to sovereignty claims or sovereign rights of any claimant State involved in the disputes. This is examined in the next section.

By contrast, the other eight specific sets of regulations referred to above appear to be generally inadequate for adoption in the Spratlys area. There are several reasons for this inadequacy. First, the mechanism may not be applicable in the Spratlys area because the corresponding instrument has not been adopted by some of the claimant States. Second, the mechanism may not be suitable because the sovereignty and maritime disputes render the application of the nomination procedure difficult or highly unlikely. For example, although all of the claimant States are a party to the World Heritage Convention, the mechanism developed for the identification of World Heritage Sites starts with the nomination of the area by a Member State on the territory of whom it is located, and provides that transboundary nominations should be prepared and submitted jointly by States parties. ${ }^{37}$ The subsequent purview of the World Heritage Committee over the admission of the site on the World Heritage List and over implementation of this convention make it unlikely for this convention to be used in the Spratlys area.

Third, the area may be too large or unusual for the type of mechanism considered. Whilst EBSAs can be very large, sensitive areas identified on the basis of the other eight sets of regulations are smaller (e.g., Ramsar Wetland Sites and World Heritage Sites). Fourth, data may be lacking. Fifth, the mechanism

London Convention for the Prevention of Marine Pollution by Dumping of Wastes and Other Matters and its 1996 Protocol and the adoption of whaling sanctuaries by the International Whaling Commission for the implementation of the 1946 International Convention for the Regulation of Whaling.

36 Of note this does not include Taiwan, which is not a member of the United Nations and is therefore unable to become a State party to international agreements.

37 Unesco, Operational Guidelines for the Implementation of the World Heritage Convention, WHC.17/01 (12 July 2017), para 134. 
may generally be ill-suited to the area. For example, the identification of the Spratlys area as a Particularly Sensitive Sea Area may be difficult as most of this area is designated on nautical charts as 'dangerous ground' where sailing should be avoided. ${ }^{38}$ Similarly, vulnerable marine ecosystems designation developed by the FAO to protect seabed habitats that are vulnerable to fisheries activities appear ill-suited for the Spratlys area as they were designed for fishing beyond national jurisdiction. ${ }^{39}$ Furthermore, there is little data on the impact of fishing in the Spratlys and there is no regional fisheries management organisation in the SCS for all the coastal States to consult and manage shared and straddling fish stocks or migratory species. ${ }^{40}$

Designation of the Spratlys area as a Ramsar site would also be difficult for most of the reasons mentioned above. Under the strict listing procedure adopted under the Ramsar Convention, candidate sites must be located on a member State's territory and designated by that member State. ${ }^{41}$ There is no provision allowing other member States to veto a site designation by another member State. However, member States have an obligation to consult with other member States over the implementation of commitments

38 Of note, groundings reported in some areas could possibly justify a case for specific routing measures to be adopted in some limited areas, provided that all the claimants States consent to it.

39 A definition and criteria for the identification of vulnerable marine ecosystems in the context of fisheries beyond national jurisdiction that were adopted by the FAO in the FAo International Guidelines for the Management of Deep-Sea Fisheries in the High Seas. See 2009 FAO International Guidelines for the Management of Deep-Sea Fisheries in the High Seas (FAO Deep-Sea Guidelines), para 6, available at http://www.fao.org/in-action/ vulnerable-marine-ecosystems/background/deep-sea-guidelines/en/; accessed 24 March 2019. Of note, despite the theoretical possibility of some areas of seabed beyond national jurisdiction in the SCS on the basis of the scs Arbitration Award, the on-going dispute on sovereignty and maritime boundaries compromises the political feasibility of applying mechanisms developed for maritime zones beyond national jurisdiction.

40 The Southeast Asian Fisheries Development Centre (SEAFDEC), which was created in 1967 to foster cooperation between governmental agencies responsible with fisheries, has become a strategic partner of ASEAN for fisheries policies in Southeast Asia. In this context, ASEAN-SEAFDEC have adopted a series of fisheries guidelines including for the protection of fisheries refugia. The SEAFDEC Guidelines on Responsible Fisheries Management provide that 'States should consider area or seasonal closure to protect critical stages of life cycles of fisheries resources'. Guidelines on fisheries refugia have been adopted subsequently. However, China is not a member of SEAFDEC, and the mandate of SEAFDEC is limited to providing data and guidance to ASEAN Member States.

41 An Introduction to the Ramsar Convention on Wetlands, 5 th Edition (Ramsar Convention Secretariat, Gland, 2016) at p. 45; Adopted by Resolution XI.8, annex 2; available at https:// www.ramsar.org/sites/default/files/documents/library/handbook1_5ed_introductionto convention_final_e.pdf; accessed 1 May 2019. 
arising from the convention on 'a wetland extending over the territories of more than one [member State] or where a water system is shared by [member States]:42 Furthermore, the Ramsar Convention has not been adopted by all claimant States and it is generally applied to shallower and coastal areas of a smaller size than the Spratlys area. Areas that are deeper than 6 metres at low tide can be included in such wetlands if they are riparian and coastal zones adjacent to wetlands and islands and bodies of marine water, especially if they support waterfowl habitat. ${ }^{43}$ The ratio of deep-water areas between seamounts, compared to shallow waters atop seamounts, makes the entire Spratlys unsuited for this mechanism under the Ramsar Convention.

\section{Prospects for the Identification of $\mathrm{EBSAs}$ under the СвD in Areas that are Subject to Sovereignty and Maritime Disputes}

The concept of an EBSA has been developed under the auspices of the COP to the $\mathrm{CBD}$ as a means to identify priority areas for biodiversity conservation in marine areas under the $\mathrm{CBD}$, especially significant marine areas in open-ocean waters and deep-sea habitats. ${ }^{44}$ It is therefore a step towards in-situ conservation and sustainable use of components of biological diversity provided for in Article $79(\mathrm{a})$ of the CBD. ${ }^{45}$

The intention of the COP to the CBD with respect to EBSAs is that the scientific data gathered for each EBSA be shared in a repository for scientific and technical information so that relevant States and competent international organisations may determine the best management measures to be adopted. Sections of the decisions of the CBD COPs that relate to the application of the criteria for EBSAs recall that it is 'a scientific and technical exercise' and that different conservation and management measures may be considered by relevant States and competent bodies including marine protected areas and impact assessment. ${ }^{46}$ They also emphasise that these measures are 'a matter for

\footnotetext{
42 Ramsar Convention (n 13), Article 5(1).

43 Ibid., Articles 1(1), 2(1).

44 CBD COP9, Decision IX/20 (n 7).

45 СвD (n 6), Article7(a) provides that a State party to the СвD shall 'identify components of biological diversity important for its conservation and sustainable use having regard to the indicative list of categories set down in Annex I'. Identification of EBSAs is an implementation step of this provision.

46 For example, see CBD COP 10, Decision X/29 (29 October 2010), para 26; and CBD COP 11, Decision XI/17 (5 December 2012), para 6.
} 
States and competent international organizations, in accordance with international law, including the [LOSC]: ${ }^{47}$

CBD COP decisions that acknowledge newly identified EBSAs and request their inclusion in the CBD repository also request that the scientific EBSA identification reports be sent to the UNGA and relevant international organisations. ${ }^{48}$ The fact that the LOSC establishes the legal framework for the restriction of any activity at sea and their management is also highlighted in each COP's decision where the LOSC is cited and referred to numerous times. ${ }^{49}$

The determination that an ocean area may meet the criteria for an EBSA is therefore akin to a screening process for marine areas that present particular ecological characteristics. This determination does not presuppose or imply that specific conservation measures must necessarily be adopted by States. From this perspective, the EBSA identification process should not appear to challenge any States' rights or interests in areas subject to sovereignty or maritime disputes. It would not prejudice the sovereignty, sovereign rights or jurisdiction of any of the claimant States, or the rights of other States under the LOSC. ${ }^{50}$ The process would in effect establish a mechanism that would enable them to cooperate to a very limited extent in furtherance of their obligation to protect and preserve the marine environment.

Since the adoption of the EBSA criteria in 2008, working groups composed of scientific experts appointed by relevant State parties and assisted by the Secretariat to the CBD, the IUCN and technical experts, have met to consider different ocean regions or sub-regions. The working groups have agreed on areas which would meet the criteria for EBSAs within each relevant region or sub-region. Their conclusions have been submitted to the Subsidiary Body on Scientific Technical and Technological Advice (sвSTTA), which subsequently decides whether to recommend them to the COP. ${ }^{51}$ This process has resulted in numerous areas of seafloor and water column of the world ocean being recognised as meeting the scientific criteria for EBSAs in need of protection. ${ }^{22}$ These areas are located within and beyond national jurisdiction.

$47 \quad$ Ibid.

$48 \mathrm{CBD} / \mathrm{COP} / \mathrm{DEC} / 14 / 9$ (28 November 2018).

49 For example, six times in СвD COP 11, Decision XI/17 and up to 20 times in СвD COP 10, Decision $\mathrm{X} / 29$.

5 O For example, CBD COP13, Decision XIII/12 (17 December 2016), para 3.

51 Dunn et al. (n 34); N Bax et al., 'Results of the efforts by the Convention on Biological Diversity to describe Ecologically or Biologically Significant Marine Areas' (2016) 30(3) Conservation Biology 571-581; DE Johnson et al., 'Reviewing the EBSA process: Improving on success' (2018) 88 Marine Policy $75^{-85}$.

$5^{2}$ Website devoted to their identification available at https://www.cbd.int/ebsa/; accessed 1 May 2019 . 
Identification of an area as an EBSA requires that the area be jointly considered and agreed-on in a regional workshop by States representatives and experts appointed by State parties. ${ }^{53}$ Johnson et al. point to political support being granted to reject or exclude some marine areas at regional workshops or at a later stage before the COP, on varying grounds best considered on a case-by-case basis. Although politically contested areas are provided as an example ${ }^{54}$ this article proposes that this political approach is inconsistent with States' obligation to protect and preserve the marine environment.

The identification of an area as an EBSA is only recognition of its ecological significance and leaves relevant States to unilaterally determine specific measures that may be needed according to international law. This creates an opportunity for cooperation without prejudice to any sovereignty or maritime dispute. However, the on-going work of the СвD to develop options for modifying the description of EBSAs, for describing new areas, and for strengthening the credibility and transparency of this process, may provide a mechanism to consider new areas or areas previously ruled out on different grounds and an opportunity for the consideration of the Spratly seamounts. ${ }^{55}$

\section{Application of the EBSA Criteria to Insular Reefs and Seamounts in the Spratlys Area}

The Spratly seamounts are oceanic reef formations in the deeper part of the scs basin between $5^{\circ} \mathrm{N}$ and $12^{\circ} \mathrm{N}$ (see Fig. 1). Their location is critical to the connectivity they provide between coastal reefs that border the scs because of the hydrodynamics ${ }^{56}$ of the basin. Since the 198 os, many authors have studied the ecological significance of the seamounts and the marine life they support. These studies have highlighted their likely importance to the coastal reefs of the scs as a source of coral larvae and as a breeding ground for migratory and regional seabirds, as well as sea turtles and commercially important fish species such as the skipjack tuna. ${ }^{57}$ Fig. 1 below provides an illustration of this connectivity for anemonefish in the scs.

53 CBD COP1o, Decision X/29, Doc. Unep/CbD/COp/Dec/X/29 (29 October 2010).

54 Johnson et al. ( $\left.\mathrm{n}_{51}\right)$.

55 CBD COP14 (2018) Resolution XIV/9 asks the Executive Secretary to identify options for modifying the EBSAs, for describing new areas, and for strengthening the scientific credibility and transparency of this process, noting the workshop report on this topic description, $\mathrm{CBD} / \mathrm{COP} / \mathrm{DEC} / 14 / 9$.

$5^{6}$ Ocean hydrodynamics refers to the physical forces that drive the motion of water such as wind, tide, density layers, topography and the shape of the ocean basin.

57 AC Alcala, 'Summary of the marine biology results of JOMSRE-SCS I, III and IV and their management implications' in Proceedings of the Conference on the Results of the PhilippineVietnam Joint Oceanographic and Marine Scientific Research Expedition in the South China 


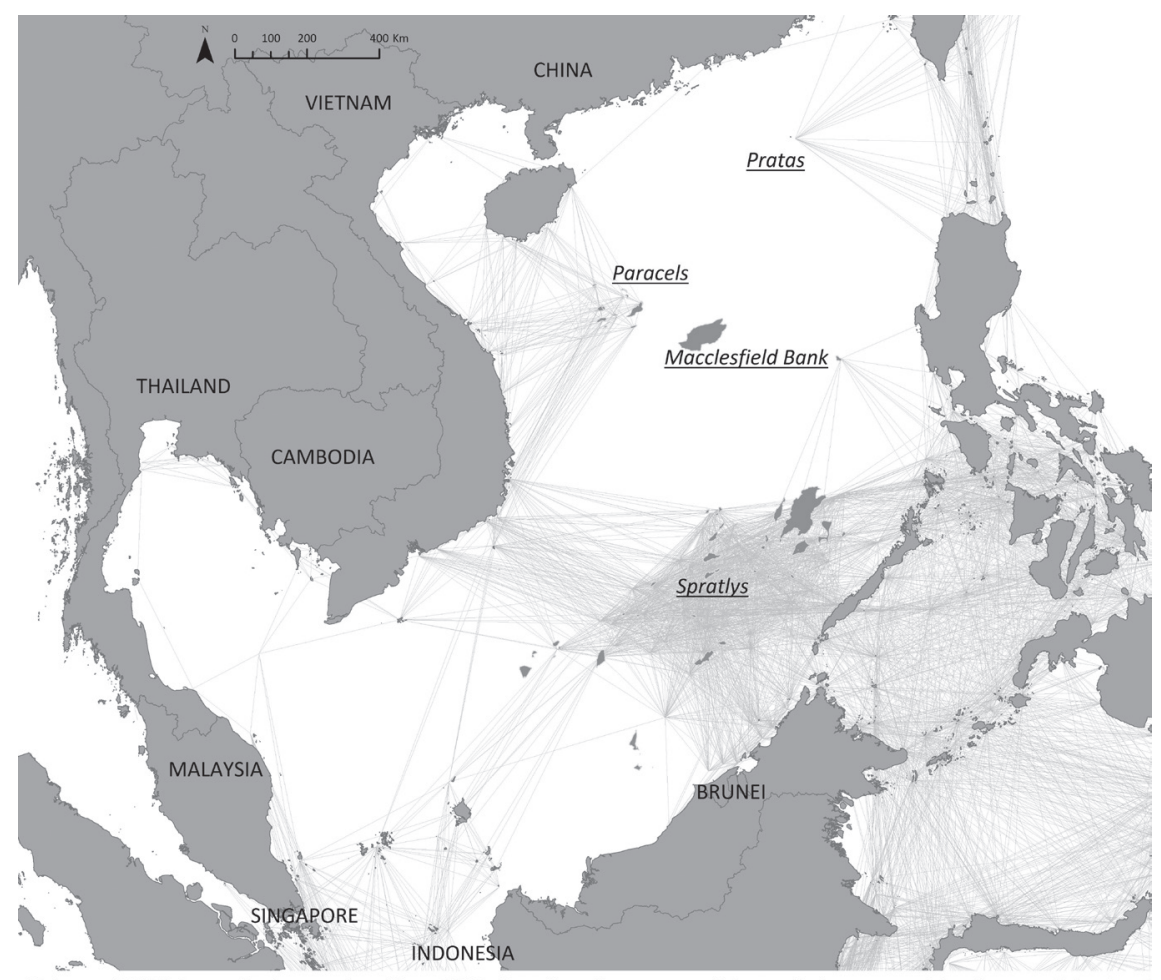

Y. Lyons (2019) Centre for International Law, NUS - Based on the anemonefish population connectivity dataset of the Coral Triangle Initiative and NUS Satellite Research Project on Insular Geographic Features in the South China Sea (2016)

FIGURE 1 Population connectivity of anemonefish in the SCS

A regional workshop to facilitate the description of ЕвSAs in the Seas of East Asia took place in 2015. However, the Spratly seamounts were not mentioned in the report of the workshop. ${ }^{58}$ The seamounts were also not included in submissions made by the parties prior to the workshop. ${ }^{59}$

Sea: JOMSRE-SCS I to IV (Ocean Friends Foundation, Dumaguete Philippines, 2008) 5-10; McManus et al. (n 1); D Huang et al., 'Extraordinary diversity of reef corals in the South China Sea' (2015) 45 Marine Biodiversity 157-168.

$5^{8}$ Report of the Regional Workshop to Facilitate the Description of Ecologically or Biologically Significant Marine Areas in the Seas of East Asia, 13-18 December 2015, Xiamen, China, Doc. UneP/CBd/EBSA/WS/2015/3/4 (11 April 2016).

59 Compilation of the Relevant Scientific Information Submitted by the Parties, other Governments and Relevant Organizations in Support of the Workshop Objectives, Doc. UNEP/CBD/EBSA/WS/2015/3/2 (12 December 2015). 
Do the seamounts in the Spratlys area meet the criteria for an EBSA? We will now examine this question..$^{60}$ Our assessment is based on a review of the published scientific literature on the Spratly seamounts, the guidance developed for the application of the criteria ${ }^{61}$ and a comparison with the evaluation of the seven criteria on the basis of which seamount areas have been identified as EBSAs in other basins. ${ }^{62} \mathrm{~A}$ rating of high, medium or low ranking of each criterion is proposed.

\section{Uniqueness and Rarity}

Seamounts are presented as a typical example for this first criterion in Appendix II to Decision IX/20, which adopted the E BSA criteria. ${ }^{63}$ The Spratly seamounts are spectacular geographic formations in the southern margin of the deep central basin of the scs. They rise from depths of up to 3,000 $\mathrm{m}$ to the photic zone - the surface layer of the ocean (typically up to 80-10o metres deep) where sunlight penetrates and allows photosynthesis to occur. Some of them are exposed at low tide, while others are deeper than $20 \mathrm{~m}$, not visible on high resolution satellite imagery and sometimes unconfirmed on nautical charts, although they are mentioned on global seamount datasets and global datasets of seabed bathymetry. ${ }^{64}$

6o A more detailed account of the scientific review made by two of the authors has been published on ssRn, available at http://dx.doi.org/10.2139/ssrn.3232743.

61 Report of the Expert Workshop on Ecological Criteria and Biogeographic Classification Systems for Marine Areas in Need of Protection, Doc. Unep/CbD/EWs.MPA $/ 1 / 2$ (13 November 2007), available at https://www.cbd.int/doc/?meeting=EWBCSIMA-o1; accessed 1 May 2019; Training Manual for the Description of Ecologically and Biologically Significant Areas (ebsas) in Open-Ocean Waters and Deep-Sea Habitats, Doc. UneP/ CBD/SBSTTA/16/INF/9 (3 May 2012).

62 PK Dunstan et al., Identifying Ecologically and Biologically Significant Areas on Seamounts: Workshop Report (IUCN, Gland, 2011), available at https://marine-conservation.org/ media/filer_public/2013/o3/21/dunstan_etal_2011.pdf. IUCN and workshop reports concerning the 44 seamount and knoll areas that were identified as meeting EBSA criteria in most of the ocean basins: 13 EBSAs in the western and South Pacific and 4 in the Wider Caribbean and Western Mid-Atlantic region (СвD СоP 11 Decision XI/17), 6 areas in the Southern Indian Ocean, 3 areas in the Eastern Tropical and Temperate Pacific, 2 areas in the North Pacific, 10 areas in the southeastern Atlantic, 2 areas in the Northwest Atlantic and 3 areas in the Mediterranean (UNEP/CBD/COP/DEC/XII/22) and one in CBD/COP/ $\mathrm{DEC} / \mathrm{XIII} / 12$.

63 Decision $\mathrm{IX} / 20\left(\mathrm{n}_{7}\right)$.

642014 SRTM15 Topography grid made available by the Scripps Institution of Oceanography University of California San Diego, available at http://topex.ucsd.edu/WWW_html/ mar_topo.html. Where the summit of these seamounts is $20 \mathrm{~m}$ deep or less and therefore visible on satellite imagery, they have been mapped and their surrounding bathymetry calculated. NUS Satellite Research Project on Insular Geographic Features in the South 
These seamounts are in a position to provide a unique network of stepping stones for vertical and horizontal connectivity. ${ }^{65}$ Furthermore, a study of 16 nearshore and offshore reef areas in the scs showed that they are distinct in coral species composition from one another ${ }^{66}$ and are therefore at higher risk of local extinction if destroyed. The coral, Leptoseris kalayaanensis, is also likely endemic to the sCs and the Spratly seamounts. ${ }^{67}$ The Spratly seamounts therefore score high on this first criterion, uniqueness and rarity.

\section{Special Importance for Life History of Species}

The Spratly reefs play major roles in maintaining and replenishing regional biodiversity. ${ }^{68}$ They provide rare shallow and suitable substrate for the recruitment of coral larvae brought by the currents generated by the monsoonal circulation patterns. ${ }^{69}$ Modelling simulations indicate that the Spratly reefs are a significant upstream source of genetic diversity for the Coral Triangle, ${ }^{70}$ because currents transport larvae originating from there to the central part of the SCS and also the western shore of Luzon and Palawan and further into the Philippines seas. The Spratlys supply larvae and young stages of fish and invertebrates to the SCS and replenishes species harvested from coastal,

China Sea. Data available at https://ormt-crisp.nus.edu.sg/ormt; and https://cil.nus.edu .sg/south-china-sea-satellite-mapping-project/.

65 In this context, stepping stone refers to a seamount providing a habitat for species/larvae from another part of the basin to settle before dispersing to yet another area. Horizontal connectivity refers, for example, to larvae from Palawan or the Sulu-Sulawesi Sea settling in the Spratlys before dispersing onto the northwestern part of the scs basin. Vertical connectivity refers to exchange between shallow and deep parts of a seamount, for example.

66 Huang et al. (n 57 ).

67 WY Licuanan and PM Aliño, 'Leptoseris kalayaanensis (Scleractinia: Agariciidae), a new coral species from the Philippines' (2009) 57 Raffles Bulletin of Zoology 1-4; BW Hoeksema et al., 'The westernmost record of the coral Leptoseris kalayaanensis in the South China Sea' (2010) 49 Zoological Studies 325; Z Waheed et al., 'Scleractinian corals (Fungiidae, Agariciidae and Euphylliidae) of Pulau Layang-Layang, Spratly Islands, with a note on Pavona maldivensis (Gardiner, 1905)' (2015) 517 ZooKeys 1-37.

68 Alcala (n 57); McManus et al. (n 1); VL Nguyen, PK Hoang, XB Hoang and B Stockwell, 'Status of marine biodiversity in the Northern Spratly Islands, South China Sea' in Proceedings of the Conference on the Results of the Philippines-Vietnam Joint Oceanic and Marine Scientific Research Expedition in the South China Sea (JOMSRE-SCS I to IV) (Dumaguete City Philippines, Oceanfriends Foundation, 2008) at pp. 11-19.

69 PT Shaw and SY Chao, 'Surface circulation in the South China Sea' (1994) 41(11/12) Deep Sea Research Part 1 1663-1683.

70 JT Kool, CB Paris, PH Barber and RK Cowen, 'Connectivity and the development of population genetic structure in Indo-West Pacific coral reef communities' (2011) 20(5) Global Ecology and Biogeography 695-706. 
nearshore reefs. ${ }^{71}$ Genetic affinities are present for some fish species ${ }^{72}$ and reef invertebrates ${ }^{73}$ between the Spratlys and the Philippines. Migratory routes of the yellowfin tuna, Thunnus albacares, pass eastwards through these seamounts from June to August and westwards from August to October. ${ }^{74}$ The Spratlys are also recorded as an important source of larvae of the coral Acropora millepora for Philippine's Palawan Reefs as well as other scs reefs. ${ }^{75}$ The Spratly reefs are also documented habitats of migratory species, especially marine sea turtles and seabirds. The migration of leatherback and green sea turtles have been observed to pass through the Spratlys seamount area. ${ }^{76}$

Nesting and feeding grounds for green turtles (Chelonia mydas) and hawksbill turtles (Eretmochelys imbricata) have been recorded around several reefs of the Spratly seamounts ${ }^{77}$ and tracks of tagged leatherbacks (Dermochelys coriacea) pass through the southern part of the area. ${ }^{78}$ These are all Appendix I species. Migratory birds such as streaked shearwater (Calonectris leucomelas), brown booby (Sula leucogaster), greater crested tern (Sterna bergii) and white

71 CF Dai and TY Fan, 'Coral fauna of Taiping Island (Itu Aba Island) in the Spratlys of the South China Sea' (1996) 436 Atoll Research Bulletin 1-21.

72 DG Ochavillo, GJ Bakus and PM Aliño, 'Identification of tropical coral reef fish larvae: MtDNA markers, morphometrics and multivariate analysis', Proceedings of the Ninth International Coral Reef Symposium (Bali, Indonesia, 23-27 October 200o) at p. 233.

73 PM Aliño and MCc Quibilan, The Kalayaan Islands: our natural heritage (Marine Science Institute, Quezon City, 2003).

74 JR Morgan and MJ Valencia, Atlas for Marine Policy in Southeast Asian Seas (University of California Press, Berkeley, 1983).

75 JG Dorman et al., 'Modeled connectivity of Acropora millepora populations from reefs of the Spratly Islands and the greater South China Sea' (2016) 35 Coral Reefs 169-179.

$76 \quad \mathrm{H}$ Bailey et al., 'Identification of distinct movement patterns in Pacific leatherback turtle populations influenced by ocean conditions' (2012) 22 Ecological Applications 735-747; P Lushi et al., (1996) 'Long-distance migration and homing after displacement in the green turtle (Chelonia mydas): A satellite tracking study' (1996) 178 Journal of Comparative Physiology A 447-452.

77 K Ibrahim, N Sulong and Z Ilias, A Survey of Marine Turtles in Pulau Layang Layang, Malaysia, Marine Biodiversity of Pulau Layang (Department of Fisheries, Layang Malaysia, 2004); J Cheng, 'Sea turtles at Taipin Tao, South China Sea' (1996) 75 Marine Turtle Newsletter 6-8.

78 SR Benson et al., 'Large-scale movements and high-use areas of western Pacific leatherback turtles, Dermochelys coriacea' (2011) 2(7) Ecosphere 84 https://doi.org/10.189o/ ES11-ooo53.1; RF Tapilatu et al., 'Long-term decline of the western Pacific leatherback, Dermochelys coriacea: A globally important sea turtle population' (2013) 4(2) Ecosphere 25 http://dx.doi.org/10.189o/ES12-00348.1; see also J Ganong, TOPP Summary of SSMderived Telemetry based Census of Marine Life Tagging of Pacific Predators, Data downloaded from овis-SEAmaP (2012 Dataset) http://seamap.env.duke.edu/dataset/632 on 15 November 2017. 
tern (Gygis alba) also use the Spratlys as a rest stop. ${ }^{79}$ The Spratlys are also a breeding ground for black-and-white sooty terns (Sterna fuscata). ${ }^{80}$

The support to gene flow and migration among deep-sea and pelagic fauna that may be provided by insular seamounts has been found to contribute to meeting the ЕвSA criteria $\mathrm{C}_{3}$ for several ЕвSA seamounts in different ocean basins. The fact that seamounts in a semi-enclosed sea may be a larval source for species that settle along the coast has been taken into account for criteria C2 of the Eastern Caribbean EBSA. ${ }^{81}$ The amount of scientific data that demonstrates the general connectivity of the Spratly seamounts with the rest of the basin for a number of species and genetic affinities for others justifies that this criterion be considered to be met at the high level.

\section{Importance for Threatened, Endangered or Declining Species and/ or Habitats}

As mentioned above, endangered marine turtles use the Spratly seamounts to nest, feed and migrate. ${ }^{82}$ Marine scientific research studies carried out in the northern Spratly seamounts area in the late 1990s and early 2000 also found that species that have become rare or extinct in other parts of the scs were found in the Spratlys, albeit in low numbers. ${ }^{83}$ These include the humphead wrasse (Cheilinus undulates), listed in Appendix II of the 1973 Convention on International Trade in Endangered Species of Wild Fauna and Flora (CITES). ${ }^{84}$ All giant clam species found in the Spratlys (Tridacna gigas, Tridacna maxima,

79 McManus et al. (n 1$)$.

8o PM Aliño et al. (eds), Atlas of Philippine Coral Reefs, (Philippine Coral Reef Information Network, Goodwill Trading Co Inc., Quezon City, Philippines, 2002) 75-77.

81 Eastern Caribbean EBSA information sheet on the Clearing-House Mechanism of the Convention on Biological Diversity Information Submission Service; available at https:// chm.cbd.int/database/record?documentID=200o97; accessed 1 May 2019.

82 See (nn $76-78)$.

83 Asian Development Bank (ADB), State of the Coral Triangle: Malaysia (Mandaluyong City, $\mathrm{ADB}, 2014)$, available at https://www.adb.org/sites/default/files/publication/42373/state -coral-triangle-malaysia.pdf; accessed 1 May 2019; HP Nguyen, 'The species composition of coral reef fishes in the Spratly Islands, Central South China Sea' in B Morton (ed), The Marine Biology of the South China Sea: Proceedings of the Third International Conference on the Marine Biology of the South China Sea, Hong Kong, 28 October - 1 November 1996 (Hong Kong University Press, Hong Kong, 1998) 113-127; Nguyen et al. (n 68).

84 Convention on International Trade in Endangered Species of Wild Fauna and Flora (Washington, 3 March 1973, in force 1 July 1975) 993 UNTS 243) (CITES). CITES seeks to protect both terrestrial and marine biodiversity by regulating international trade in specimens of CITES-listed species to certain controls. The level of protection given to a species depends on which of the three appendices it is listed within CITES. Appendix I species are granted the highest protection. 
Tridacna squamosa and Hippopus hippopus) are also listed on cites Appendix II and threatened with extinction if urgent measures are not taken to stop harvesting and trade. ${ }^{85}$ The sperm whale (Physeter microcephalus), now on CITES Appendix I, had been recorded by sailors regularly in the late eighteenth and early nineteenth century. ${ }^{86}$ However, there appears to be no record included since in central datasets. Sperm whales may not have been the subject of particular attention in the region since that time.

Five species of mobulid rays are known to be found in the scs where they used to be abundant: Mobula japonica, Mobula tarapacana, Mobula eregoodootenkee, Mobula kuhlii and Mobula thurstoni. ${ }^{87}$ Two endangered species of sharks that are listed on Cites Appendix II have been found (albeit in low numbers due to their persistent overfishing) as bycatch of tuna longlining fisheries in the Spratlys: the hammerhead shark (Sphyrna mokarran) and the pelagic tresher shark (Alopias pelagigus). ${ }^{88}$ The whale shark (Rhincodon typus) is also reported by blogs from divers around Swallow Reef.

The presence of species such as the cheeklined wrasse, Cheilinus diagrammus, listed under Cites Appendix II, ${ }^{89}$ and the green humphead parrotfish, Bolbometopon muricatum, in the IUCN Red List ${ }^{90}$ have been recorded from the Spratlys.

The Spratly seamounts therefore appear to host a number of species that are recognised as being endangered under international law. However, a lack of systematic and species-specific records justifies that this criterion be met at the medium to high level.

85 ML Neo et al., 'Giant clams (Bivalvia: Tridacninae): A comprehensive update of species and their distribution, current threats and conservation status' (2017) 55 Oceanography and Marine Biology-An Annual Review 85-388; Y Lyons, D Cheong, ML Neo and HF Wong, 'Managing giant clams in the South China Sea' (2018) 33 International Journal of Marine and Coastal Law 1-28.

86 G Woolmer, Historical Distribution of Whales Shown by Logbook Records 1785-1913 (2013 Dataset); data downloaded from овIS-SEAmAP http://seamap.env.duke.edu/dataset/885 on 15 November 2017.

87 A Ali, 'Introduction to species (Mobula rays)', SEAFDEC Expert Meeting on the Commercially-exploited Aquatic Species (16-17 May 2016, Bangkok); N Picher, S Oakley and G Ismail, Layang Layang, A Drop in the Ocean (Natural History Publications Borneo, Kota Kinabalu, 1999).

88 S. Putsa, I Chanrachkij and S Promjinda, Shark Species in Tuna Longline Fishing Operation by SEAFDEC Research Vessels (2005-2015) (SEAFDEC, Bangkok, 2016), available at http:// www.seafdec.org/documents/2016/o5/em-ceas_agenda5td.pdf; accessed 1 May 2019.

$89 \quad$ Nguyen (n 83).

9o Nguyen et al. (n 68). 


\section{Vulnerability, Fragility, Sensitivity, Slow Recovery}

Sixty-eight coral species occurring in Spratlys are listed as 'vulnerable to extinction'.91 The sCs is also expected to be the subject of high ocean acidification, higher than in the Pacific around Hawaii and in the Atlantic around Bermuda. ${ }^{92}$

The report, which summarises how the seamounts off the Cook Islands meet the EBSA criteria, indicate that the vulnerability, fragility, sensitivity or slow recovery is rated as high on the basis of a high proportion of sensitive habitats, biotopes or species being functionally fragile. ${ }^{93}$ On this basis, the Spratly seamounts also meet this criterion at the high level.

\section{Biological Productivity}

Heileman describes the scs Large Marine Ecosystem (LME) as a moderate production ecosystem, ${ }^{94}$ while capture fisheries data show high fisheries productivity of $13.7 \%$ of the global capture fisheries production in 2000 to $21.5 \%$ of the global capture fisheries production in $2014 .{ }^{95}$ The area of the Spratly seamounts is a well-known and regionally important fishing grounds for reef fish as well as associated pelagic fisheries such as tuna and mackerel. ${ }^{96}$ However, several studies report that this apparent increase in capture fisheries production hides a decrease in volume of larger predatory fish such as tuna and grouper, which

$91 \quad$ IUCN, The IUCN Red List of Threatened Species (2015-Version 2014.3) downloaded from http://www.iucnredlist.org.

92 TH Huang and TA Cheng, 'The influence of anthropogenic $\mathrm{CO}_{2}$ in the South China Sea', Conference Proceedings of the International Conference on Marine Environment and Biodiversity Conservation in the South China Sea (Conference Proceedings, 16-17 July 2010, National Sun Yat-sen University, Kaohsiung, Taiwan).

93 СвD, 'Ua Puakaoa Seamounts in the Western South Pacific Region', in Report of the Western South Pacific Regional Workshop to Facilitate the Description of Ecologically or Biologically Significant Marine Areas, Doc. Unep/CBd/sbStTA/16/INF/6 (11 April 2012), 23-25, available at https://www.cbd.int/doc/meetings/mar/rwebsa-wspac-ol/official/rwebsa-wspac -o1-sbstta-16-inf-o6-en.pdf; accessed 1 May 2019.

94 S Heileman, 'VIII-15 South China Sea LME', in K Sherman (ed), UNEP Large Marine Ecosystem Report: A Perspective on Changing Conditions in the LMES of the World's Regional Seas (2009), available at http://lme.edc.uri.edu/images/Content/LME_Briefs/ lme_36.pdf; accessed 1 May 2019 .

95 SEAFDEC, The Southeast Asian State of Fisheries and Aquaculture 2017 (Southeast Asian Fisheries Centre, Bangkok , 2017), available at http://www.seafdec.org/; accessed 1 May 2019.

96 PM Aliño, CL Nañola, DG Ochavillo and MC Rañola, 'The Fisheries Potential of the Kalayaan Island Group, South China Sea', in B Morton (ed), The Marine Biology of the South China Sea, Proceedings of the Third International Conference on the Marine Biology of the South China Sea, 28 October-1 November 1996 (Hong Kong University Press, Hong Kong, 1998) 219-226; Nguyen et al. (n 68). 
are being gradually replaced by smaller fish that feed on zooplankton. ${ }^{97}$ The precise contribution of the Spratly seamounts to capture fisheries production is unclear.

Generally over the scs, upwelling during the northeast monsoon enhances chlorophyll $a$ concentrations in the surface layer of upwelling areas. ${ }^{98}$ The reef waters are described as generally oligotrophic waters with low nutrient concentrations. ${ }^{99}$ However, visible sea surface temperature fronts can be observed throughout the year in the Spratlys area, albeit more accentuated in summer. ${ }^{100}$ Biological productivity of the area of the Spratly seamounts is greater than surrounding oceanic waters and can be rated as medium. However, this is the weakest criterion. It is reasonable to consider that it is met at the low level.

\section{Biological Diversity}

Coral reefs that have the highest level of coral species richness in the SCS have developed on the Spratly seamounts, with 333 coral species, $58 \%$ of the total coral species diversity in the SCS, or $55 \%$ of the 605 species in the Coral Triangle. ${ }^{101}$ More coral reef fish species have also been recorded on one of the seamounts (Swallow Reef) than on any other coral reef area of Malaysia. ${ }^{102}$ Whilst there had been some anecdotal evidence of the presence of deepwater corals in the Spratlys, recent surveys demonstrate the validity of the

97 VT Christensen, LR Garces, G Silvestre and D Pauly, 'Fisheries impacts on the South China Sea Large Marine Ecosystem: A preliminary analysis using spatially-explicit methodology', in G Silvestre et al. (eds), Assessment, Management and Future Directions for Coastal Fisheries in Asian Countries -Worldfish Center Conference Proceedings 67 (2003) 51-62; B Stockwell and VL Nguyen, 'Reef fish stocks of the Northern Spratly Islands: A summary of the findings of JOMSRE-SCS III and JOMSRE-SCS IV' in Proceedings of the Conference on the Results of the Philippines-Vietnam Joint Oceanic and Marine Scientific Research Expedition in the South China sea (JOMSRE-SCS I to IV) (Dumaguete City Philippines, Oceanfriends Foundation Inc, 2008) at pp. 21-35.

98 CTA Chen, SL Wang, BJ Wang and S.C. Pai, 'Nutrient budgets for the South China Sea basin' (2001) 75 Marine Chemistry 281-300.

99 TD Hoang, HT Pham, MF Cayme and JL Pinanonang, 'Some aspects of chemical oceanography in reef waters of the Spratly Islands, South China Sea', in Proceedings of the Conference on the Results of the Philippine-Vietnam Joint Oceanographic and Marine Scientific Research Expedition in the South China Sea (JOMSRE-SCS I to IV) (Dumaguete City Philippines, Oceanfriends Foundation Inc, 2008) at pp. 185-195.

100 MA Lee and Y Chang, 'sst fronts in the South China Sea', in A.K. Liu, C.T. Liu, M.K. Hsu and J. Hu (eds), Satellite Remote Sensing of South China Sea (Tingmao Publish Company, Taipei-Taiwan, 2008) at p. 187-198.

101 Huang et al. (n 57); Waheed et al. (n 67).

102 Maritime Institute Malaysia, Malaysia National Coral Reef Report (UNEP-GEF Project and Marine Park Section, Ministry of Natural Resources and Environment, 2006, Malaysia); Nguyen et al. (n 68). 
hypothesis that they should be found. Surveys have so far been limited to the outer margin of Vietnam (western Spratlys) and some transects in the northern part of the Spratlys. Over 24 species have been identified in 12 stations of the western Spratlys (at a depth of 150 to $400 \mathrm{~m}$ ). ${ }^{103}$ In their 2009 book, Roberts et al. reported only two species on the margin of the scs: Madrepora oculata and Goniocorella dumosa. ${ }^{104}$ Dai reports 190 species of deep-sea scleractinians identified around Pratas Island, Macclesfield Bank and Itu Aba and found that their distribution and community structure suggests that the scs might host a very high diversity of them. ${ }^{105}$ Scientific workshops which have concluded that seamounts meet the EBSA criteria of biological diversity rely on a presumption of species richness.

When there is a lack of data, the analyses tend to rely on the geophysical characteristics of seamounts, namely, the fact that they extend several thousands of metres from the seafloor to the photic zone and have steep slopes thereby supporting a variety of habitats and biotopes ${ }^{106}$ and therefore a variety of conditions that affect faunal composition. This is presumed to translate into high biodiversity, especially in tropical seas, for example, the Ua Puakaoa Seamounts, the Kadavu and the Southern Lau Region. ${ }^{107}$ This reasoning can be applied to the Spratly seamounts, which extend from a depth of 1,000-3,000 m to the surface or near-surface. ${ }^{108}$ On these bases, the Spratly seamounts meet the criterion of biological diversity at the medium level.

\section{Naturalness}

The Spratly seamounts are isolated oceanic seamounts and difficult to access. This characteristic has provided some natural protection against human activities and development. However, human activities have been reported in this area (especially from fishing, including destructive fishing practices, and building of offshore installations and other infrastructures on

\footnotetext{
103 YA Latypov, 'A solitary deep-water corals of the scleractinian of the Vietnamese Shelf' (2014) 2(1) American Journal of Zoological Research 5-15.

104 JM Roberts, A Wheeler, A Freiwald and S Cairns, Cold-Water Corals: The Biology and Geology of Deep-Sea Coral Habitats (Cambridge University Press, Cambridge, 2009).

105 CF Dai, 'Octocorals and deep-sea scleractinians in the South China Sea', in 2017 International Symposium on Coral Reef Conservation in the South China Sea, 5-7 November 2017 (Academia Sinica, Taipei-Taiwan, 2017).

106 A biotope is an area of uniform environmental condition associated with a particular ecological community.

107 Workshop Report (n 93).

108 Nautical charts 17010 to 1880o, Navigation Guarantee Department of the Chinese Navy Headquarters (China), 2005-2013.
} 
reefs). Decreased biomass and localised reef destruction have been widely reported. ${ }^{109}$ Based on the geographic isolation and the general inaccessibility of theSpratly seamounts, due to the large area covered and water depth in between seamounts, this seventh criterion of 'naturalness' is considered to be met at the medium level.

\section{Discussion}

The literature review of the ecological characteristics of the Spratly seamounts shows that these seamounts would meet all seven EBSA criteria albeit with varying strengths. Biological productivity is the weakest criterion based on the generally oligotrophic characteristic of the area. ${ }^{110}$ However, relatively higher productivity is expected around the shallow or exposed parts of seamounts. It is noted that few models are at a scale where discrete areas of higher productivity can be identified. Despite lacking data, the Spratly seamounts score high on three criteria and medium on three others (due partly to data gaps). Based on prior identification of EBSAS and endorsements by the COP to the CBD, this should be sufficient for them to qualify as an EBSA under the СвD.

However, the Spratlys area extends over several hundred kilometres from north to south and west to east. When considering what specific appropriate management actions could be taken by claimant States and which subsets of the Spratlys area are to be prioritised, several studies can be considered, such as those that would identify areas that are connectivity nodes for larval dispersal ${ }^{111}$ and of particular importance for conserving distinctive species assemblages. ${ }^{112}$ Based on records of reef scleractinian corals found at five localities, ${ }^{113}$ from

109 AC Alcala, 'Summary of the marine biology results of JOMSRE-SCS I, III and IV and their management implications,' in Proceedings of the Conference on the Results of the Philippine-Vietnam Joint Oceanographic and Marine Scientific Research Expedition in the South China Sea (JOMSRE-SCS Ito IV) (Technical Cooperation Council of the Philippines of the Department of Foreign Affairs, Philippines, 2008) $5^{-10}$. See also the sCs Arbitration Award (n 4); CH Nguyen and HD Vu, 'Environmental issues in the South China Sea: Legal obligation and cooperation drivers' (2018) 1(1) International Journal of Law and Public Administration 8-23.

110 An oligotrophic water body is characterised by low nutrient levels.

111 In this context, connectivity nodes refer to areas of habitats and their associated communities that can host species and enable their dispersal beyond the typical geographic range of their larvae.

112 A species assemblage is a group of organisms belonging to different species that co-occur in a specific habitat and interact through different types of relationships.

113 CF Dai and TY Fan, 'Coral fauna of Taiping Island (Itu Aba Island) in the Spratlys of the South China Sea' (1996) 436 Atoll Research Bulletin 1-21; H Huang et al., 'Scleractinian coral community characteristics in Zhubi reef sea area of Nansha Islands' (2012) $3^{1}$ Journal of Oceanography in Taiwan Strait 79-84; YY Latypov, 'Scleractinian corals and 
Subi Reef at the northwestern part of the Spratlys to Swallow Reef at the south, the species composition in the northernmost locality (Subi Reef) is more distinctive than in the south (Swallow Reef). The assemblages in the northern part (Subi and Itu Aba) are also more similar to reef communities in the northern South China Sea, including the Paracel Islands and southern China, with Subi Reef's species composition being more similar to the northern scs than the others. ${ }^{114}$

Therefore, in order to protect and preserve the South China Sea effectively, the northern part of the Spratlys may be a priority area for protection and conservation on this basis. Furthermore, management measures should ensure that the connectivity between sites such as Subi Reef and the other parts of the basin is maintained. Given the scarcity of ecological data on the Spratlys, it would be worthwhile for future research to focus on identifying comparable sites in the northern Spratlys in order to ensure connectivity and build basinwide resilience among marine communities that can better resist deteriorating changes over time.

\section{Measures that May Be Adopted from a Legal and Political Perspective}

\section{States' Obligations under International Law with Respect to EBSAs}

States' obligations under LOSC with respect to activities in EBSAs that are under their jurisdiction or control include measures to ensure the protection and preservation of rare or fragile ecosystems as well as the habitat of depleted, threatened or endangered species and other forms of marine life. This includes the duty to prevent the harvest of endangered species. ${ }^{115}$ States must

reefs of Vietnam as a part of the Pacific reef ecosystem' (2011) 1 Open Journal of Marine Science 50-68, doi:10.4236/ojms.2011.12006; N Pilcher and A Cabanban, The Status of Coral Reefs in Eastern Malaysia (Australian Institute of Marine Science, Townsville, 200o); Z Waheed, F Benzoni, SET van der Meij, TI Terraneo and BW Hoeksema, 'Scleractinian corals (Fungiidae, Agariciidae and Euphylliidae) of Pulau Layang-Layang, Spratly Islands, with a note on Pavona maldivensis (Gardiner, 1905)' (2015) 517 ZooKeys 1-37, doi:10.3897/ zookeys.517.9308; MX Zhao et al., 'Coral communities of the remote atoll reefs in the Nansha Islands, southern South China Sea' (2013) 185 Environmental Monitoring and Assessment 7381-7392, doi:10.1007/s10661-013-3107-5.

114 Dataset and R script for this analysis are available at https://dx.doi.org/10.5281/ zenodo.26o7o86.

$115 \operatorname{LOSC}(\mathrm{n} 4)$, Articles 192, 194(5). See also the legal findings of the Tribunal in the SCS Arbitration Award and application of Article 194(5) that coral reefs in the Spratlys are 'rare or fragile ecosystems' as well as the habitats of 'depleted, threatened or endangered 
also monitor the risks or effects of activities and publish the resulting environmental impact assessments. ${ }^{116}$ Consistent with these provisions, States must, under the СвD, 'identify processes and categories of activities which have or are likely to have significant adverse impacts on the conservation and sustainable use of biological diversity and monitor their effects through sampling and other techniques'. In addition, States have the obligation to maintain and organise data derived from monitoring and identification of marine biodiversity. ${ }^{117}$

These obligations can therefore be fulfilled by the claimant States in the Spratlys area if they all agree to monitor activities on and surrounding the features they occupy as well as the activities of their nationals and vessels flying their flag in these areas. In order to avoid sensitivities linked to the perception of accepting the status quo by 'accepting' (even without prejudice) the occupation of features by specific claimants, claimants could agree to focus their control over activities by vessels flying their flag and by persons under their 'jurisdiction and control', without any reference to effective control over different areas of the Spratlys (or specific geographic limits). This monitoring and reporting arrangement would be possible if all of the claimant States agree that cooperation in establishing the EBSA is without prejudice to the sovereignty and maritime disputes in the South China Sea.

Following this rationale, the State with effective control over a feature and its surrounding waters would in practice monitor and report on the components of biodiversity within this area, thereby complying with the LOSC and the СBD. According to the objectives of the ASEAN-China Strategy on Environmental Cooperation 2016-2020, publication of the reports could be organised through the ASEAN Centre for Biodiversity. These objectives read:

To further develop and implement the ASEAN-China Cooperation Plan on Biodiversity and Ecological Conservation in collaboration with ASEAN Centre for Biodiversity, so as to improve China and [ASEAN Member States] capacity and consciousness in ... implementing the Convention on Biological Diversity and other international obligations, and promoting the conservation, management and sustainable use of biological resources. [emphasis added]

species' including the giant clam, the hawksbill sea turtle and certain species of coral and fish. scs Arbitration Award (n 4), para 945.

$116 \operatorname{LOSC}(\mathrm{n} 4)$, Articles 204-206.

117 СвD (n 6), Articles 7(c) and (d). 
Such a cooperative arrangement would also be consistent with the 2002 Declaration on the Conduct of Parties in the South China Sea. ${ }^{118}$ The 2002 Declaration provides that pending a comprehensive and durable settlement of the territorial and jurisdictional disputes, the parties concerned may explore or undertake cooperative activities on marine environmental protection.

The States bordering the scs are currently engaged in discussions on the management of the marine environment in this area in the context of the ASEAN plus China cooperation. They have also been in negotiations for several years on the development of a Code of Conduct in the South China Sea. ${ }^{119}$ Such an arrangement would also be consistent with these efforts.

\section{Proposed Areas: Where and Why?}

The Entire Sea Area Including the Spratly Seamounts?

The proposed area could initially be the entire area comprising the Spratly seamounts. This area consists of some very small islands and numerous low-tide elevations ${ }^{120}$ and submerged coral reefs. It is not near any shipping lanes, so it would not interfere with international shipping and international trade.

The fact that there have been extensive building activities on some of the Spratly seamounts ${ }^{121}$ and that they have caused serious damage to the coral system and the marine life it supports, may be used to argue that the Spratlys area as a whole do not meet the EBSA criteria. However, naturalness is only one of the alternative ЕвSA criteria. Many others are met. Furthermore, including the entire Spratlys area in the proposed EBSA would enable States to understand the extent to which the damaged ecosystems are recovering.

The claimant States may want to take a gradual approach when imposing limitations on human activities in the area. ${ }^{122}$ Initially they may want to impose complete bans on certain types of fishing, such as dynamite or cyanide fishing or fishing methods that involve the excavation of reef flats, in order to comply with international law. Seasonal closures could also be imposed on

118 Declaration on the Conduct of the Parties in the South China Sea (Phnom Penh, 4 November 2002), available at http://asean.org/?static_post=declaration-on-the -conduct-of-parties-in-the-south-china-sea-2; accessed 1 May 2019.

119 HT Nguyen, 'The 2002 Declaration on the Conduct of the Parties in the South China Sea: a Note' (2002) 34 Ocean Development \& International Law 279-285.

120 A low-tide elevation is a naturally formed area of land which is surrounded by and above water at low tide but submerged at high tide. LOsc (n 4), Article 13.

121 SCs Arbitration Award (n 4), paras 976-983.

122 For a comparable proposal focused on joint development, see AH Oegroseno, 'State practices in Southeast Asia: Possible collaboration amongst claimants in the South China Sea Dispute' (2017) 32 International Journal of Marine and Coastal Law 364-372. 
other types of fishing or for specific species. They may also want to agree to adopt strict rules to prevent pollution of the marine environment from all activities on the islands they occupy, including the disposal of garbage, human waste, etc. A gradual approach is more likely to build trust and confidence in the process. On the basis of available data, reefs in the northern part of the Spratlys could be focused on as a start. Then, after the data have been collected for several years, the States may want to review the results and decide upon more specific restrictions and/or to focus on more specific locations.

\section{For Further Research on Connectivity, Species Composition}

Distinctiveness and Rarity

As previously discussed, the maintenance of a sufficient number of connectivity nodes is necessary to increase the resilience of coral reefs in the northern part of the scs. This article also suggests some priority areas for protection based on similarity in species composition between the reefs in the northern Spratlys and those of the northern scs (with Subi Reef, which is geographically the closest to Vietnam and located at the northwestern outskirt of the Spratly seamounts, being the most similar). However, site selection must balance sites with close similarity in species comparison with the need to ensure that connectivity is also ensured for rare coral species. The presence of rare species on various reef sites must therefore also be taken into account.

A practical approach to this need of data could be fulfilled as a cooperative mechanism between the claimant States that occupy features in the northern part of the Spratlys, with a preference for those located in the northwestern part. Complex reef structures which are the subject of less activity may be preferred in that respect. The advantage of such research steps is that they are to be performed unilaterally by each State over the reef areas it controls. As an example, China could provide additional data from Subi Reef and Fiery Cross Reef; Vietnam could provide data on South West Cay or South Reef (on North Danger Reef) and Discovery Great Reef and Small Reef; and the Philippines could provide data on sites on Loaita Bank and West York Island. For such an effort to be successful, the data provided would need to meet an agreed protocol on site selection (e.g., reef flat, slope), survey methodology (e.g., transect, timed swim or manta tow) and species targeted (e.g., specific taxonomic groups or all species in the area).

If the above recommendations are adopted, a critical area for marine biodiversity in Southeast Asia will have a degree of protection, and none of the claimant States will have compromised their positions on the sovereignty and maritime disputes. 


\section{Conclusion}

The view of the authors is that there is a compelling case for the claimant States to cooperate in the identification of the Spratly seamounts as an EBSA, so long as it is agreed by all the claimant States that such cooperation is on a 'without prejudice' basis. Cooperation on the identification of EBSAs could be used to foster cooperation whilst also contributing to the fulfilment of the States' obligations to protect and preserve the marine environment. These obligations of States under the LOSC, as complemented by the СвD, must be fulfilled with due diligence, especially with respect to rare, depleted, threatened, endangered or fragile species, habitats and ecosystems.

By contrast with the identification of EBSAs, the extent of the States' obligation to restrict activities in an EBSA would depend on the risks posed by different activities to the marine environment in this area. Assessment of the risks would take into account the nature of the sensitivity identified and the actual or potential impacts of the activities considered. In order to apply to all claimant States, the decision would have to be made jointly by these States directly or through the competent regional or international body for each activity considered. ${ }^{123}$

123 Acknowledgement: No funding was provided for the joint academic investigation that resulted in this article. The authors would like to thank Ms Choo Min for her help with the data used for the analysis. This article is an updated and expanded version of a joint paper by Youna Lyons and Robert Beckman presented by Robert Beckman at the APOLIA Conference on area-based marine protection in the Asia-Pacific, which took place in Sydney, Australia on 18-19 August 2018. 